\title{
THE INFLUENCE OF LEADERSHIP STYLES ON EMPLOYEE PERFORMANCE IN CONSTRUCTION FIRMS
}

\author{
Jean Luc Kalambayi ${ }^{1}$ \\ ${ }^{1}$ Graduate Centre for Management ${ }^{2}$ \\ ${ }^{2}$ Cape Peninsula University of Technology \\ Cape Town, South Africa, 7535 \\ Darlington Peter Onojaefe $\boldsymbol{I}^{ }$ \\ onojaefed@cput.ac.za \\ Sophie Nguepi Kasse ${ }^{I}$ \\ Robertson K. Tengeh \\ Department of Public Administration \& Governance ${ }^{2}$
}

$\triangle$ Corresponding author

\begin{abstract}
Currently, there is a dearth of research, examining how project managers' leadership styles influence the performance of construction company workers in Cape Town. Other research has discussed this subject on a national or international level. Still, comprehensive data on Cape Town construction firms is lacking. This has prevented local enterprises from understanding the role of their project managers' leadership styles on employee performance outcomes. This article sought to ascertain how leadership styles influence employee performance in construction firms and to develop a conceptual framework for improving leadership and performance. Through quantitative techniques, 456 questionnaires were distributed at construction sites across Cape Town. Responses were then analysed using an ANOVA test (with the descriptive and regressive methods) and a post-hoc test (using the Bonferroni Method) and correlation analysis. The results reveal a statistically significant positive relationship between project managers' leadership styles and the performance of subordinate employees. These findings have subsequently been used to develop a conceptual framework of leadership quality development tools, including training, empowerment, coaching, participation, and delegation. The research contributes to new knowledge that will promote local project managers' leadership development, improve employee performance, and in doing so, increase successful project outcomes across the city.

Keywords: project management, leadership style, transformative leadership, transactional leadership, autocratic leadership, democratic leadership, employee performance, construction industry.
\end{abstract}

DOI: $10.21303 / 2504-5571.2021 .002037$

\section{Introduction}

The construction industry is a vital sector of any country's economic output; the industry plays a crucial role in contributing to national targets for physical, economic, and social needs [1]. Likewise, Cape Town's construction industry plays an integral part in shaping the city's past, present, and future. In an era of globalisation, "the physical infrastructure, built through construction activity, is the nation's economic backbone... [it] can influence the competitiveness of enterprises within the economy" [2].

The absence of leadership in the construction industry can be devastating [3]; without it, teams stall, flounder, and miss project goals entirely. While most literature to date recognises the importance of leadership, the research often emphasises the role of technical aspects in determining a project's success or failure, rather than adequately addressing management style and leadership [3]. "The low volume of leadership studies in the South African industry is due to the lack of knowledge of the industry on the part of social scientists and a lack of understanding of social sciences by those in the industry" [2].

To address this gap in understanding, this study investigated how democratic, transactional, transformative, or autocratic leadership styles influence the performance of construction employees in Cape Town. It considered leadership style variables to be independent and the performance of employees to be dependent. The study developed a relationship analysis model to demonstrate which of these four styles were most effective for employee performance, based on data from construction companies and active job sites across the city. 
The first phase of the research included the review of existing literature resources and relevant empirical studies. The second phase focused on collecting primary data from construction project managers and employees in the construction industry in Cape Town through a quantitative questionnaire. In total, 456 structured questionnaires were distributed to employees of all management levels on job sites and the offices of construction companies in Cape Town as part of a purposive sample group. These questionnaires were divided into three sections: Section A gathered respondent demographics; Section B explored leadership styles and their impact on employees' performance using a Likert scale ranking system; Section $\mathrm{C}$ asked optional open-ended questions about the different attributes, competencies, and characteristics of project managers that could impact employees' performance in the Cape Town's construction sector.

Despite technological advancements in project management, many projects continue to fail. The success of a project is partially determined by how well the manager manages the scope, money, time and quality limitations. To do this, the project manager must possess and demonstrate effective project management leadership [4]. The performance of projects is a significant issue for all grassroots, national, and international development organizations. Billions of dollars have been invested in community initiatives to improve people's living situations throughout the world. Empirical research indicates that fewer than half of poverty eradication and community-based project projects in Africa ever achieve their intended outcomes. For a long time, leadership has been a critical component in determining workplace innovation and performance [5]. This article aims to ascertain the extent of the impact of managers' leadership style on employee performance.

The literature review addresses each of the main leadership styles and theories and information about how these styles apply to and impact employee performance in the construction industry in Cape Town. This lays a foundation for the theoretical and conceptual framework and addresses the research questions and objectives.

The definition of leadership can prove as elusive to pin down as its true beginnings. Philosophers and great minds of the ancient world used the concept with various connotations. Thus, it can have nuanced perceptions depending on its context. Goethals et al. [6] argue that some of the first references to leadership can be found in texts from the Far East as early as the 6th century BC, with Chinese masters, such as Lao Tzu and Zhuang Zhao, advocating for "selflessness and leadership" in their works. Other philosophers, including Aristotle, Plato, Machiavelli, and Confucius, also contributed their own opinions to the theoretical database of knowledge on leadership. "These efforts and other philosophical approaches constitute a rich and ongoing normative approach to understanding leadership", states Liphadzi [2], adding that they attach a moral or ethical significance to good leaders. He argues that most modern-day theories on leadership are not unique, and heavily borrow from the historical or classical views of leadership.

Cape Town's construction industry is integral to the livelihoods of Cape Town residents [2]. It impacts employment opportunities, economic growth, environmental sustainability outcomes, and overall health and wellbeing [2]. Despite its significance, however, no recent literature has been written that details the impact of Cape Town's project managers' leadership styles on employee performance. While one study by Liphadzi [2], explores the effects of leadership in construction across South Africa, it did not provide Cape Town-specific data or analysis. Likewise, another study by the University of Cape Town researchers investigated the challenges that impact the national industry's performance, development, and growth by interviewing 120 construction employees in Cape Town. Yet their work points to material costs, access to mortgage/credits, interest rates, and contracting enterprises' success as main determinants of how, well or poorly, projects will perform-not the leadership style of a project manager [7].

As such, this study seeks to determine what leadership-related factors impact the success or failure of projects. With no recent studies to bolster the literature review, historical sources have been consulted for evidence, indicating how the industry in Cape Town has evolved to its present-day state. The authors have also reviewed related studies from non-local sources.

To understand the impact of leadership styles on employee performance, the meaning of 'leadership' must first be explored. Most scholars use a terminology that relates to responsibility, influence, personality, or status, a method to achieve a goal or set of desired behaviours [8]. 
Leadership styles are "managerial attitudes, behaviours, characteristics and skills," which are defined by both individual and collective interests, reliability, and values [9]. Zulch [10] points to eight main styles of leadership: directive, bureaucratic, pacesetting, participative, visionary, coaching, laissez-faire and affiliative. These leadership styles can directly impact employees' performance, productivity, and commitment; they can positively or negatively affect a team [2].

This study focuses on four main leadership styles and defines them in greater detail in the pages to follow: autocratic, democratic, transactional, and transformational leadership.

The authoritarian-style leader takes sole responsibility for decision making with little input. While autocratic leadership can prove helpful in projects, requiring split-second decisions, it can also lead to resentment among subordinates if they feel overworked and undervalued [11]. In the construction industry, the autocratic project management leadership style is helpful when a project faces urgent and stressful problems: missed deadlines, a lack of available labour and materials, or the risk of excessive change orders. As potential concerns arise, it can benefit a project manager to take immediate action without extensive consultation [12]. However, the lack of consultation can result in subordinates, revolting against the rigidity of structure [12].

Democratic leadership involves everyone in decisions, from the lowest subordinate to the highest-ranking executive [13]. A participative leader expects subordinates to be skilled and confident problem solvers. They are asked to contribute ideas, opinions, and skills; each can vote or decide outcomes. No single person has the final say; it is a group effort that considers all needs and wants [14]. A democratic leadership style can inspire collaboration, encourage teamwork, and increase performance in the construction industry. When individuals feel personally invested, they are likely to work together towards positive outcomes [14]. This includes working overtime, managing time and material resources, and respecting teammates [14]. However, this leadership style can take longer to build consensus; it can easily lead to cost and time overruns [14]. Employees also may not fully understand the complexities of the client and may make decisions based on their own interests. Likewise, a louder majority can quash individual opinions and those of minorities [15].

Transactional leadership encourages obedience and implementation through rewards and punishments. It underlies most leadership models and is highly motivating for short-term results [16]. Increased wages, reduced hours, and weekends off can be promised in exchange for desired outcomes; likewise, penalties can be leveraged to minimise unwanted behaviours [2]. In the long-term, transactional leadership can lead to burnout or an unhealthy environment where employees only perform under the promise of incentives or the threat of punishments.

Transformational leaders encourage, inspire, and motivate employees. They boost performance through charisma or idealised influence, inspirational motivation, intellectual stimulation, and personal and individual attention [17]. In the construction industry, this leadership style encourages active involvement from employees, despite the fact all final decisions rest with the project manager. Transformational leadership can yield more varied, efficient, and innovative ideas and decrease employee dissatisfaction, burnout, absenteeism, and turnover. This leadership style drives positive employee performance and encourages personal growth and learning, including upskilling and promotions [2]. However, when leaders encourage ideas from employees but do not take their advice for final decisions, it can lead to decreased satisfaction and dwindling performance if employees feel their views are consistently ignored. Likewise, if a transformational project manager loses employee trust, it can be catastrophic for morale and projects [18].

Study objective was to ascertain the extent of the influence of managers' leadership style on employee performance.

\section{Research design and methodology}

This section details methods and rationale for data collection and analysis. It explains the processes, used to collect, present, analyse, and validate data, to respond to the research questions.

This study used quantitative methods to gather objective scientific evidence on the leadership styles of project managers in Cape Town and the potential influence these leadership styles have on the performance of construction employees. Structured questionnaires were designed to allow the survey of project managers and construction employees in Cape Town and systematically 
investigate the primary data, gathered using statistical and mathematical methods. Positivism was identified as the primary research paradigm, an approach that "relies specifically on scientific evidence, such as experiments and statistics, to reveal a true nature of how society operates" [19].

According to Brent and Leedy [20], research design is "the plan for a study." It provides the overarching structure for data collection and a comprehensive empirical outline for data collection that aids researchers in testing their hypotheses, answering specific research questions, and developing processes for data collection and sampling [21]. This study adopted a descriptive survey design to accurately examine the behaviour, opinion, abilities, beliefs, and knowledge of project managers and construction employees in Cape Town.

Research for this thesis was conducted in two parts: the first phase focused on reviewing existing literature from reports, journals, articles, and books. The second phase included collecting and analysing primary data from construction project managers and employees in the construction industry in Cape Town through a structured questionnaire.

In total, 456 questionnaires were distributed to employees of all management levels at job sites and construction companies in Cape Town through non-probability (or purposive) sampling. The questionnaires were divided into three sections: Section A collected demographic characteristics of respondents; Section B used a five-point Likert scale to measure the impact of leadership styles on employee performance and develop a conceptual framework to improve leadership and employee performance; Section $\mathrm{C}$ provided space for respondents to answer open-ended questions or provide details on their responses, free of the constraints of the Likert scale.

Data analysis is the process of studying, organising, transforming, and modeling data [22]. It aims to uncover useful information, reach fact-based conclusions, and help make informed decisions [22].

The data from completed questionnaires was systematically investigated using statistical and mathematical methods, with the help of the computer software system, SPSS (Statistical Package for Social Science). The data was analysed using descriptive statistics in the form of proportions, frequencies, means and standard deviations, independent t-tests, and paired t-tests to compare differences between two groups, as well as correlation and Analysis of Variance (ANOVA) tests. A conceptual framework was then developed based on the theoretical framework and empirical data analysis. It is hoped that the framework presented would help to understand the influencing factors, contributing an improved leadership style and employee performance in construction firms.

In this study, the computer software system SPSS (Statistical Package for the Social Sciences) was used to analyse each numerical response on the Likert scale-style questionnaire and calculate the mean-item score (MIS) and standard deviation (Fig. 1 and $\mathbf{2}$ below). The Likert scale is an accurate, valid, and reliable tool for data design and analysis, according to measurement specialists, since it analyses multiple-item composites [23, 24].

The MIS was ranked in descending order (from highest to lowest) as shown in Fig. 1 below. The figure compares the respondents' perceived importance of each statement. Standard deviation demonstrates how respondents' answers varied from the mean - for example, whether responses were concentrated around the middle ground ' 3 ' of the Likert scale, or if they bordered on the extremes of the scale (a ' 1 ' or ' 5 ').

The researcher used regression analysis and a reliability test to analyse the accuracy of the Likert-scale results using Cronbach's alpha coefficient. This reliability test revealed the impact of leadership styles on employee performance in the Cape Town construction industry has a Cronbach's alpha reliability coefficient of 0.894 . A Cronbach's alpha of 0.80 and above is considered highly accurate in social science research situations, with 0.90 considered the best [27].

The study also used a post-hoc test (Bonferroni method) and correlation and Analysis of Variance (ANOVA) to compare and reveal the differences between the means of the independent and dependent variable groups and ensure the validity of the results. When considering the data analysis technique to implement for this study, the authors evaluated the potential strengths and limitations of both ANOVA and t-test. According to Hopkins [27], ANOVA's post hoc tests allow for increased control over type-I errors, which occur when the null hypothesis proves true, but is nevertheless rejected. For this reason, ANOVA was selected as the data analysis technique for hypothesis testing in this study. 


\begin{tabular}{|l|l|}
\hline Category ranking & Mean Item Score (MIS) \\
\hline $1=$ Not at all & MIS $=1 \mathrm{n} 1+2 \mathrm{n} 2+3 \mathrm{n} 3+4 \mathrm{n} 4+5 \mathrm{n} 5 \ldots \ldots \ldots \ldots$ Equation 1 \\
$2=$ To some extent & $\sum \mathrm{N}$ \\
$3=$ To a moderate extent & where, \\
$4=$ To a great extent & $\mathrm{N} 1=$ number of respondents for strongly disagree \\
$5=$ To a very great extent & $\mathrm{N} 2=$ number of respondents for disagree \\
& $\mathrm{N} 3=$ number of respondents for neutral \\
& $\mathrm{N} 4=$ number of respondents for agree \\
& $\mathrm{N} 5=$ number of respondents for strongly agree \\
& $\mathrm{N}=$ Total number of respondents \\
\hline
\end{tabular}

Fig. 1. Calculating Mean Item Score (MIS) on a five-point Likert scale. Source:

Lim and Alum (1995)[25]

\begin{tabular}{|l|l|}
\hline Category ranking & Standard deviation equation \\
\hline $\begin{array}{l}1=\text { Strongly Disagree } \\
2=\text { Disagree } \\
3=\text { Neutral } \\
\begin{array}{l}4=\text { Agree } \\
5=\text { Strongly Agree }\end{array}\end{array}$ & $S=\sqrt{\frac{1}{N-1} \sum_{i=1}^{N}\left(x_{i}-\bar{x}\right)^{2}}$ \\
& $\begin{array}{l}\mathrm{S}=\text { Sample standard deviation } \\
\mathrm{N}=\text { The number of data points } \\
\mathrm{X}=\text { Each of the value of the data } \\
\overline{\mathrm{X}}=\text { Sample mean } \\
\mathrm{i}=1 \text { Number of the value in the data } \\
\sum=\text { Sum of }\end{array}$ \\
\hline
\end{tabular}

Fig. 2. Calculating Standard Deviation on a five-point Likert scale Source:

Elaine R Monsen (2007:5) [26]

\section{Result}

This section includes the results and discussion of the researcher's data collection and analysis to determine if the research questions were addressed.

\section{1. Questionnaire Section A: Demography}

This section of the research questionnaire assessed the background information of respondents, gathering primary data about respondents' general characteristics in a quantifiable manner:

\section{Gender}

Of 377 duly completed questionnaires, data revealed $89.1 \%$ of respondents identified as male (336 in total) and $10.9 \%$ identified as female (41). No respondents identified as 'other' (i. e. gender non-binary or non-conformant).

\section{Age}

Data revealed the majority of respondents were between the ages of 26 and 35 (43.5\%), followed by those between the ages of 36 and 45 (26.3\%). Those between the ages of 0 to 25 ranked third $(15.6 \%)$, while only $8.5 \%$ of respondents were between 46 and 55 years. The least prominent were older employees aged 56 to 65 (4\%) and 66 to 75 years old $(2.1 \%)$.

\section{Race}

Cape Town is a diverse cultural landscape, with people from across Africa and the world. Just over half of respondents (50.9\%) identified as Black, followed by those who identified as Coloured (30\%). Only $19.1 \%$ of respondents identified as White. No one identified as a race other than the above groups.

\section{Professional title}

Based on their professional title, $7.7 \%$ of respondents said they were project managers. Only $2.9 \%$ were subcontractors, and $2.7 \%$ were general contractors. In total, $86.7 \%$ said they were general construction workers, team members, and labourers. 


\section{Educational qualifications}

The highest percentage of respondents were educated at the secondary school level and graduated with matric (43\%), while $27.1 \%$ listed themselves as having university or college qualifications. A further $19.1 \%$ of respondents had graduated with primary school qualifications, and $10.9 \%$ said they had 'no schooling' or had not completed primary school.

\section{Industry experience}

Data revealed nearly half of respondents (48\%) had worked between one to five years, followed by $28.9 \%$ of respondents, who said they had less than a year of experience. The numbers were lower for those with more experience: $15.9 \%$ for the 5 - to 15 -year category, $5 \%$ for those with 16 to 30 years, and only $2.1 \%$ for those with 31 to 50 years of experience.

\section{2. Questionnaire Section B: Leadership style and performance}

The results of Section B of the questionnaire reveal how transactional, transformational, democratic, and autocratic leadership are used by project managers in Cape Town and how the implementation of leadership styles can impact employee performance in the local construction industry. This portion of the questionnaire required respondents to use a Likert-scale ranking system (a ' 1 ' on the scale indicated strong disagreement with the statement, while a ' 5 ' meant they strongly agreed). The data was analysed using descriptive statistics, including analysis of proportions, mean, standard deviation, and regression analysis.

\section{Leadership styles: ranked from most- to least-commonly used}

Data from respondents revealed a transactional leadership style is used often (Table 1). Notably, these findings differ from the results of a similar study by Liphadzi [2], which evaluated leadership styles and their impact on employee performance in the construction industry. Liphadzi's [2] work found transformational leadership to be more commonly utilised by project managers at a national level; transactional leadership was ranked second most popular across the country.

Table 1

Common use ranking of leadership style

\begin{tabular}{ccc}
\hline Project managers' leadership style & Mean \pm Standard deviation error & Rank \\
\hline Transactional leadership & $4.06 \pm 0.35$ & 1 \\
Democratic leadership & $3.88 \pm 0.27$ & 2 \\
Transformational leadership & $3.86 \pm 0.15$ & 3 \\
Autocratic leadership & $3.61 \pm 0.24$ & 4
\end{tabular}

\section{The influence of leadership style}

On the impact of project managers' leadership style on employees' performance, from most to least influence. The data revealed that transactional leadership has the most significant influence on employee performance, and construction employees' performance was strongly influenced by rewards and punishments (Table 2).

Table 2

The influence of leadership style

\begin{tabular}{ccc}
\hline Leadership style & Mean \pm Standard deviation & Rank \\
\hline Transactional leadership & $4.07 \pm 0.59$ & 1 \\
Transformational leadership & $4.03 \pm 0.38$ & 2 \\
Democratic leadership & $3.83 \pm 0.51$ & 3 \\
Autocratic leadership & $2.63 \pm 0.81$ & 4
\end{tabular}

\section{Questionnaire Section C: Open questions}

Section $\mathrm{C}$ of the questionnaire was designed to investigate the attributes, possessed by construction project managers in Cape Town; identify which were liked or disliked by respondents and which positively or negatively impacted performance. Respondents were able to give feedback without the constraints of a quantitative scale or numerical ranking system. 
The research revealed:

- Many respondents said they appreciated when their project leader took the initiative and "went the extra mile" to accomplish project tasks.

- Respondents said they appreciated when their project manager took the time to listen to others' suggestions, incorporating them in decision making.

- Respondents cited project managers' lack of collaboration and communication with team members as an issue.

- Several other factors were indicated to influence performance, both positively and negatively; racial divides in the workplace, for example, affected performance negatively, whereas financial benefits or incentives, new project challenges, good communication, a sense of belonging, and an ability to meet project goals and objectives all impacted performance positively.

\section{Descriptive analysis}

"Descriptive statistics are used to present quantitative descriptions in a manageable form" and simplify vast amounts of data in a logical matter [28]. This method uses tables, discussion, figures, and graphs to represent variability - also known as the measure of central tendency - to assist readers in understanding the data that has been collected. To interpret the key results for this research, the size of the sample was first outlined, describing the central tendency of the data collected, highlighting the spread of the data, assessing the data distribution's shape and spread, and comparing data from different survey groups.

Tables 3, 4 show the distribution scores of project managers' leadership styles and employee performance. The sample consisted of 377 participants, including project managers and subordinate employees. It provides a statistical summary of the number of samples $(\mathrm{N})$ and the measures used (i.e. mean, standard deviation, and standard deviation error, etc.) to investigate the statistical differences in the mean rating of leadership styles and their impact on employee performance.

Table 3

Descriptive analysis of leadership styles in the construction industry in Cape Town

\begin{tabular}{|c|c|c|c|c|c|c|c|c|c|}
\hline & \multirow{2}{*}{ Leadership styles } & \multirow[b]{2}{*}{$\mathbf{N}$} & \multirow[b]{2}{*}{ Mean } & \multirow{2}{*}{$\begin{array}{l}\text { Std. De- } \\
\text { viation }\end{array}$} & \multirow{2}{*}{$\begin{array}{l}\text { Std. } \\
\text { Error }\end{array}$} & \multicolumn{2}{|c|}{$\begin{array}{l}95 \% \text { Confidence } \\
\text { Interval for Mean } \\
\end{array}$} & \multirow{2}{*}{$\begin{array}{l}\text { Mini- } \\
\text { mum }\end{array}$} & \multirow{2}{*}{$\begin{array}{c}\text { Maxi- } \\
\text { mum }\end{array}$} \\
\hline & & & & & & $\begin{array}{l}\text { Lower } \\
\text { Bound }\end{array}$ & $\begin{array}{l}\text { Upper } \\
\text { Bound }\end{array}$ & & \\
\hline \multirow{5}{*}{ LSSM } & Transformational Leadership & 377 & 3.8640 & 0.36997 & 0.16546 & 3.4046 & 4.3234 & 3.54 & 4.44 \\
\hline & Transactional Leadership & 377 & 4.0600 & 0.34641 & 0.15492 & 3.6299 & 4.4901 & 3.68 & 4.60 \\
\hline & Democratic Leadership & 377 & 3.8800 & 0.61008 & 0.27284 & 3.1225 & 4.6375 & 3.02 & 4.60 \\
\hline & Autocratic Leadership & 377 & 3.6120 & 0.53490 & 0.23922 & 2.9478 & 4.2762 & 2.86 & 4.28 \\
\hline & Total & 1508 & 3.8540 & 0.46846 & 0.10475 & 3.6348 & 4.0732 & 2.86 & 4.60 \\
\hline
\end{tabular}

The mean in Tables 3, 4 have been used to measure each variable's centre of a numerical data set. On the other hand, the standard deviation indicates how many individual responses to questions vary or 'deviate' from the mean. These numbers highlight the spread of the responses. These two tables also show the 'level of confidence interval', representing the true population mean. The authors can have $95 \%$ confidence that the population mean lies between the lower and upper bounds based on the analysis. In Table 5 above, the descriptive analysis of the leadership style of construction project managers is demonstrated, abbreviated as 'LSSM'. Scores for LSSM ranged from 2.86 to 4.60 , with a mean of 3.8540 and a standard deviation of 0.46846 . Table 6 below depicts the descriptive analysis for employee performance - abbreviated as 'ULSSIEM'. Scores for ULSSIEM ranged from 1.58 to 4.49 with a mean of 3.6445 and a standard deviation of 0.81764 .

Below, Table 5 summarises the ANOVA analysis of project managers' leadership styles and employee performance in Cape Town's construction industry. This hypothesis test uses "the ratio of between-group variation to within-group variation" to reveal if there is a statistically significant difference between the groups; "within-group variation" measures the extent, to which an individual mean varies from the group mean [29]. 
Table 4

Descriptive analysis of employee performance in Cape Town's construction industry

\begin{tabular}{|c|c|c|c|c|c|c|c|c|c|}
\hline & \multirow{2}{*}{$\begin{array}{l}\text { Leadership styles } \\
\text { Transformational Leadership }\end{array}$} & \multirow{2}{*}{$\frac{\mathbf{N}}{377}$} & \multirow{2}{*}{$\begin{array}{l}\text { Mean } \\
4.0320\end{array}$} & \multirow{2}{*}{$\begin{array}{c}\begin{array}{c}\text { Std. Devi- } \\
\text { ation }\end{array} \\
0.38245\end{array}$} & \multirow{2}{*}{$\begin{array}{c}\begin{array}{c}\text { Std. } \\
\text { Error }\end{array} \\
0.17104\end{array}$} & \multicolumn{2}{|c|}{$\begin{array}{l}95 \% \text { Confidence } \\
\text { Interval for Mean }\end{array}$} & \multirow{2}{*}{$\begin{array}{c}\begin{array}{c}\text { Mini- } \\
\text { mum }\end{array} \\
3.42\end{array}$} & \multirow{2}{*}{$\begin{array}{c}\begin{array}{c}\text { Maxi- } \\
\text { mum }\end{array} \\
4.34\end{array}$} \\
\hline \multirow{5}{*}{ ULSSIEM } & & & & & & 3.5571 & 4.5069 & & \\
\hline & Transactional Leadership & 377 & 4.0760 & 0.59932 & 0.26802 & 3.3319 & 4.8201 & 3.05 & 4.49 \\
\hline & Democratic Leadership & 377 & 3.8340 & 0.51520 & 0.23040 & 3.1943 & 4.4737 & 3.42 & 4.46 \\
\hline & Autocratic Leadership & 377 & 2.6360 & 0.81730 & 0.36551 & 1.6212 & 3.6508 & 1.58 & 3.43 \\
\hline & Total & 1508 & 3.6445 & 0.81764 & 0.18283 & 3.2618 & 4.0272 & 1.58 & 4.49 \\
\hline
\end{tabular}

To prepare for the ANOVA test, depicted in Table 5, participants were divided into two groups, based on their respective scores for the independent variable (or leadership styles, written below as LSSM) and the dependent variable (employee performance, abbreviated below as ULSSIEM). In advance of regression analysis, a one-way ANOVA test was conducted to determine if there was a statistically significant impact between leadership styles and employee performance - in other words, if there was a marked difference in employee performance between the leadership styles and if a particular leadership style impacted employees to perform better. Here, a p-value of less or equal to 0.05 was required two show significance (the 'Sig.' column).

Table 5

Hypothesis testing: ANOVA for leadership styles and employee performance

\begin{tabular}{|c|c|c|c|c|c|c|}
\hline & ANOVA Test & Sum of Squares & df & Mean Square & $\mathbf{F}$ & Sig. \\
\hline \multirow{3}{*}{ LSSM } & Between Groups (LSSM) & 0.509 & 3 & 0.170 & 0.741 & 0.543 \\
\hline & Within Groups (ULSSIEM) & 3.661 & 16 & 0.229 & & \\
\hline & Total & 4.170 & 19 & & & \\
\hline \multirow{3}{*}{ ULSSIEM } & Between Groups (LSSM) & 6.947 & 3 & 2.316 & 6.437 & 0.005 \\
\hline & Within Groups (ULSSIEM) & 5.755 & 16 & 0.360 & & \\
\hline & Total & 12.702 & 19 & & & \\
\hline
\end{tabular}

*At the 0.05 level, the mean difference is significant

The data revealed the ANOVA for employee performance was significant since $\mathrm{F}(3.16)=6.437$, and the $\mathrm{p}$-value $=0.005$. This result allowed the researcher to reject the null hypothesis (H0), which stated: "There is no statistically significant impact of the leadership style of project managers on employee performance." Based on these results, project managers' leadership styles do have a statistically significant impact on employee performance.

To fully understand the statistical impact between leadership style and employee performance in ANOVA, a post-hoc test was subsequently conducted on previously analysed subset data between groups to confirm where the differences occurred between groups of variables (specifically, a multiple comparison analysis tests, as seen in Table 6). The study used the multiple comparison method by Bonferroni, which provides a post-hoc comparison of the means, to determine which means were significantly different. This ensures a statistical adjustment to the significance level of hypothesis tests, since multiple tests were performed. This reduces the probability of identifying significant results that do not exist, and in doing so, guards against making Type I errors (where the null hypothesis is rejected) when it was, in fact, true in the testing process.

The post-hoc test result using the Bonferroni method indicated a statistically significant difference between the impact of the transformational, transactional, and democratic leadership styles, and the autocratic leadership style, as shown by a Sig. value of less than 0.05 . This implies that autocratic leadership had the most negligible impact on employee performance in the construction industry in Cape Town and an impact magnitude that was statistically significant relative to all other leadership styles. 
Table 6

Comparison test of leadership styles and employee performance using the Bonferroni method

\begin{tabular}{|c|c|c|c|c|c|c|c|}
\hline \multirow{2}{*}{ Bonferroni Method Test } & \multirow{2}{*}{ (I) $\mathrm{LS}$} & \multirow{2}{*}{ (J) LS } & \multirow{2}{*}{$\begin{array}{c}\text { Mean } \\
\text { Difference } \\
\text { (I-J) }\end{array}$} & \multirow{2}{*}{ Std. Error } & \multirow{2}{*}{ Sig. } & \multicolumn{2}{|c|}{$\begin{array}{c}95 \% \text { Confidence } \\
\text { Interval }\end{array}$} \\
\hline & & & & & & $\begin{array}{l}\text { Lower } \\
\text { Bound }\end{array}$ & $\begin{array}{l}\text { Upper } \\
\text { Bound }\end{array}$ \\
\hline \multirow{11}{*}{ Bonferroni } & \multirow{3}{*}{$\begin{array}{c}\text { Transfor- } \\
\text { mational } \\
\text { Leadership }\end{array}$} & $\begin{array}{l}\text { Transactional } \\
\text { Leadership }\end{array}$ & -0.19600 & 0.30252 & 1.000 & -1.1061 & 0.7141 \\
\hline & & $\begin{array}{l}\text { Democratic Lead- } \\
\text { ership }\end{array}$ & -0.01600 & 0.30252 & 1.000 & -0.9261 & 0.8941 \\
\hline & & $\begin{array}{c}\text { Autocratic Lead- } \\
\text { ership }\end{array}$ & 0.25200 & 0.30252 & 1.000 & -0.6581 & 1.1621 \\
\hline & \multirow{3}{*}{$\begin{array}{l}\text { Transfor- } \\
\text { mational } \\
\text { Leadership }\end{array}$} & $\begin{array}{l}\text { Transactional } \\
\text { Leadership }\end{array}$ & 0.19600 & 0.30252 & 1.000 & -0.7141 & 1.1061 \\
\hline & & $\begin{array}{c}\text { Democratic Lead- } \\
\text { ership }\end{array}$ & 0.18000 & 0.30252 & 1.000 & -0.7301 & 1.0901 \\
\hline & & $\begin{array}{l}\text { Autocratic Lead- } \\
\text { ership }\end{array}$ & 0.44800 & 0.30252 & 0.948 & -0.4621 & 1.3581 \\
\hline & \multirow{3}{*}{$\begin{array}{l}\text { Democratic } \\
\text { Leadership }\end{array}$} & $\begin{array}{l}\text { Transformational } \\
\text { Leadership }\end{array}$ & 0.01600 & 0.30252 & 1.000 & -0.8941 & 0.9261 \\
\hline & & $\begin{array}{l}\text { Transactional } \\
\text { Leadership }\end{array}$ & -0.18000 & 0.30252 & 1.000 & -1.0901 & 0.7301 \\
\hline & & $\begin{array}{l}\text { Autocratic Lead- } \\
\text { ership }\end{array}$ & 0.26800 & 0.30252 & 1.000 & -0.6421 & 1.1781 \\
\hline & & $\begin{array}{l}\text { Transformational } \\
\text { Leadership }\end{array}$ & -0.25200 & 0.30252 & 1.000 & -1.1621 & 0.6581 \\
\hline & $\begin{array}{l}\text { Autocratic } \\
\text { Leadership }\end{array}$ & $\begin{array}{l}\text { Transactional } \\
\text { Leadership }\end{array}$ & -0.44800 & 0.30252 & 0.948 & -1.3581 & 0.4621 \\
\hline & & $\begin{array}{c}\text { Democratic Lead- } \\
\text { ership }\end{array}$ & -0.26800 & 0.30252 & 1.000 & -1.1781 & 0.6421 \\
\hline \multirow{12}{*}{ ULSSIEM } & \multirow{3}{*}{$\begin{array}{c}\text { Transfor- } \\
\text { mational } \\
\text { Leadership }\end{array}$} & $\begin{array}{l}\text { Transactional } \\
\text { Leadership }\end{array}$ & -0.04400 & 0.37932 & 1.000 & -1.1851 & 1.0971 \\
\hline & & $\begin{array}{c}\text { Democratic Lead- } \\
\text { ership }\end{array}$ & -0.19800 & 0.37932 & 1.000 & -0.9431 & 1.3391 \\
\hline & & $\begin{array}{c}\text { Autocratic Lead- } \\
\text { ership }\end{array}$ & $1.39600^{*}$ & 0.37932 & 0.012 & 0.2549 & 2.5371 \\
\hline & \multirow{3}{*}{$\begin{array}{c}\text { Trans- } \\
\text { actional } \\
\text { Leadership }\end{array}$} & $\begin{array}{l}\text { Transformational } \\
\text { Leadership }\end{array}$ & 0.04400 & 0.37932 & 1.000 & -1.0971 & 1.1851 \\
\hline & & $\begin{array}{c}\text { Democratic Lead- } \\
\text { ership }\end{array}$ & 0.24200 & 0.37932 & 1.000 & -0.8991 & 1.3831 \\
\hline & & $\begin{array}{c}\text { Autocratic Lead- } \\
\text { ership }\end{array}$ & $1.44000^{*}$ & 0.37932 & 0.010 & 0.2989 & 2.5811 \\
\hline & \multirow{3}{*}{$\begin{array}{l}\text { Democratic } \\
\text { Leadership }\end{array}$} & $\begin{array}{l}\text { Transformational } \\
\text { Leadership }\end{array}$ & -0.19800 & 0.37932 & 1.000 & -1.3391 & 0.9431 \\
\hline & & $\begin{array}{l}\text { Transactional } \\
\text { Leadership }\end{array}$ & -0.24200 & 0.37932 & 1.000 & -1.3831 & 0.8991 \\
\hline & & $\begin{array}{c}\text { Autocratic Lead- } \\
\text { ership }\end{array}$ & $1.19800^{*}$ & 0.37932 & 0.037 & 0.0569 & 2.3391 \\
\hline & \multirow{3}{*}{$\begin{array}{l}\text { Autocratic } \\
\text { Leadership }\end{array}$} & $\begin{array}{l}\text { Transformational } \\
\text { Leadership }\end{array}$ & $-1.39600^{*}$ & 0.37932 & 0.012 & -2.5371 & -0.2549 \\
\hline & & $\begin{array}{l}\text { Transactional } \\
\text { Leadership }\end{array}$ & $-1.44000^{*}$ & 0.37932 & 0.010 & -2.5811 & -0.2989 \\
\hline & & $\begin{array}{c}\text { Democratic Lead- } \\
\text { ership }\end{array}$ & $-1.19800^{*}$ & 0.37932 & 0.037 & -2.3391 & -0.0569 \\
\hline
\end{tabular}

* The mean difference is significant at the 0.05 level. 


\section{Regression analysis and correlation results}

Regression analysis is a statistical technique, used to estimate the relationship among variables that have a "reason-and-result relation" [30]. Its primary intent is to examine the relationship between a dependent variable and each independent variable and formulate the linear relation equation between dependent and independent variables. Since the regression model for this study used just one dependent variable but more than one independent variable, this study used multilinear regression. Regression analysis is a form of inferential statistics, whereby p-values help determine if relationships the researcher observes in a sample also occur in the larger population. The null hypothesis can be tested using the $\mathrm{p}$-value for each independent variable to determine if it correlates with the dependent variable. If there is no association between the changes in an independent variable and the dependent variable, then no correlation exists. When this happens, there is insufficient evidence to demonstrate a cause-effect relationship among the larger population scientifically. If a variable's p-value is less than the significance level, it means the sample data provides sufficient evidence to reject the entire population's null hypothesis. The data thus favours the hypothesis, stating a non-zero correlation. In addition, it suggests that changes in the independent variable are associated with changes among the population level. As such, this variable is revealed as statistically significant and useful as an addition to the regression model. However, when a p-value is greater than the significance level, this means there is a lack of evidence in the sample to conclude that a non-zero correlation exists.

This study performed a regression analysis to determine the correlation between leadership styles and employee performance and to make predictions through interpreting this relationship. This analysis assisted in assessing the hypotheses for Research Question Two. Table 7 shows the research key results for descriptive statistics.

Table 7

Regression analysis of leadership styles and employee performance - simple linear regression descriptives and correlation output

\begin{tabular}{cccc}
\hline Regression Analysis & Mean & Std. Deviation & N \\
\hline Transformational Leadership & 193.2000 & 16.97552 & 377 \\
Transactional Leadership & 203.0000 & 15.89439 & 377 \\
Democratic Leadership & 194.0000 & 27.99248 & 377 \\
Autocratic Leadership & 180.6000 & 24.54298 & 377 \\
Ascertaining the extent of the impact of leadership style on & 1112.6000 & 244.38158 & 1508 \\
employees' performance & &
\end{tabular}

A correlation matrix was also developed (Table 8), along with probability values for all variables. There is only one correlation coefficient since there were only two variables, leadership styles (independent) and employee performance (dependent). The results indicate that all leadership styles were highly correlated with employee performance, but showed a difference in the magnitude of all Pearson moment correlation coefficient ranges between 0.88 and 0.97 .

This implies a strong positive and significant relationship between employee performance and the different leadership styles, employed by project managers in Cape Town's construction industry. The strength of the relationship between leadership styles and employee performance, numerically measured, was 1.00 . A correlation of $r=1.000 ; p<0.05$ suggests a strong positive relationship between leadership styles and employee performance.

In Table 9, the model summary provides the correlation coefficient and coefficient of determination (r-square or $\mathrm{r} 2$ ) for the regression model. As stated, a coefficient of 0.94 suggests a strong positive relationship between leadership styles and employee performance, while $r 2=0.94$ (94\%) suggests the independent variable has a strong positive impact on employee performance. This implies that $94 \%$ of variations in the perceived employee performance can be explained by the type of leadership styles the project managers adopted. Table 11 shows the full model is statistically significant $(\mathrm{F}=0.741 ; \mathrm{df}=4,15$; Sig. F Change $=0.000$ ). This statistic reveals that if the chosen significance level is less than 0.05 , the researcher can discard the null hypothesis and conclude the alternative of the overall significance of lead- 
ership styles as a determinant of employee performance. The F-test affirmed that leadership styles could effectively and efficiently enhance employee performance in the construction industry in Cape Town.

Table 8

Correlation matrix of leadership styles and employee performance

\begin{tabular}{|c|c|c|c|c|c|c|}
\hline \multicolumn{2}{|c|}{ Correlation Matrix } & AEILSEP** & $\begin{array}{l}\text { Transformational } \\
\text { Leadership }\end{array}$ & $\begin{array}{c}\text { Transactional } \\
\text { Leadership }\end{array}$ & $\begin{array}{l}\text { Democratic } \\
\text { Leadership }\end{array}$ & $\begin{array}{l}\text { Autocratic } \\
\text { Leadership }\end{array}$ \\
\hline \multirow{5}{*}{$\begin{array}{l}\text { Pearson Cor- } \\
\text { relation }\end{array}$} & AEILSEP** & 1.000 & & & & \\
\hline & $\begin{array}{l}\text { Transforma- } \\
\text { tional Leader- } \\
\text { ship }\end{array}$ & $0.978 * * *$ & 1.000 & & & \\
\hline & $\begin{array}{l}\text { Transactional } \\
\text { Leadership }\end{array}$ & $0.943 * * *$ & $0.967 * * *$ & 1.000 & & \\
\hline & $\begin{array}{l}\text { Democratic } \\
\text { Leadership }\end{array}$ & $0.887 * * *$ & $0.858 * * *$ & $0.938 * * *$ & 1.000 & \\
\hline & $\begin{array}{l}\text { Autocratic } \\
\text { Leadership }\end{array}$ & $0.918 * * *$ & $0.902^{* * *}$ & $0.958^{* * *}$ & $0.991 * * *$ & 1.000 \\
\hline
\end{tabular}

The correlation is significant at the 0.05 level (1 tailed) *, **,*** represented significance at $10 \%, 5 \%$ and $1 \%$ respectively **AEILSEP = Ascertaining the extent of the impact of leadership style on employee performance

Table 9

Model summary and coefficients

\begin{tabular}{|c|c|c|c|c|c|c|}
\hline \multicolumn{7}{|c|}{ Model Summaryb } \\
\hline Model & & & ge St & & & \\
\hline $\begin{array}{c}\text { R Square } \\
\text { Change }\end{array}$ & & hange & df1 & df 2 & Sig. F Change & Durbin-Watson \\
\hline 1 & $0.94^{\mathrm{a}}$ & 10555.200 & 4 & 15 & .000 & 2.960 \\
\hline
\end{tabular}

a. Predictors: (Constant), Autocratic Leadership, Transformational Leadership, Transactional Leadership, Democratic Leadership / b. Dependent Variable: Ascertaining the extent of the impact of leadership style on employees' performance

\begin{tabular}{|c|c|c|c|c|c|c|}
\hline \multicolumn{7}{|c|}{ Coefficients } \\
\hline & \multirow{2}{*}{ Model } & \multicolumn{2}{|c|}{ Unstandardized Coefficients } & \multirow{2}{*}{$\begin{array}{l}\text { Standardized Coefficients } \\
\text { Beta }\end{array}$} & \multirow{2}{*}{$\mathrm{t}$} & \multirow{2}{*}{ Sig. } \\
\hline \multirow{6}{*}{1} & & $\mathrm{~B}$ & Std. Error & & & \\
\hline & (Constant) & -698.536 & 0.000 & & -7663192.452 & .000 \\
\hline & Transformational Leadership & 27.292 & 0.000 & 1.896 & 19884448.693 & .000 \\
\hline & Transactional Leadership & -20.648 & 0.000 & -1.343 & -1707288.489 & .000 \\
\hline & Democratic Leadership & 15.641 & 0.000 & 1.792 & 9749420.295 & .000 \\
\hline & Autocratic Leadership & -12.760 & 0.000 & -1.281 & -6596007.191 & .000 \\
\hline
\end{tabular}

a. Dependent Variable: Employees' performance

In this case, the results mean the null hypothesis ( $\mathrm{H} 0)$ should be rejected. The coefficients table gives us the values for the regression line; the adjusted R-squared coefficient for this regression model is 1.000 , which means leadership styles have a $100 \%$ impact on employee performance. Moreover, the regression coefficient result revealed transactional and autocratic leadership styles had a negative impact on employees' performance, while democratic and transformational leadership showed a positive impact. As such, the null hypothesis was discarded based on the coefficients table and its values for the regression line (as the F-stat probability was less than 0.05 ).

\section{Conceptual framework}

To develop a conceptual framework that may improve leadership quality and employee performance, the questionnaire asked respondents to use the five-point Likert scale to rank which potential tools could help improve their daily performance. The results were as seen in Table $\mathbf{1 0 .}$ 
Table 10

Conceptual framework action and the means to achieve it

Conceptual framework action
Learning and improving skills
Promote a willingness to admit and learn from failures or
weaknesses
Improve communication skills and the flow of informa-
tion within the project team and the company
Maintain a positive attitude throughout the project or at
work

Set definitive goals and follow through on action plans

\begin{abstract}
Course of action/means
Workshops, courses, or training

Facilitate communication, learn from others, workshops, courses, or training

Facilitate meetings, make communication a priority, develop active listening skills, respect your audience

Fill the mind with positive input, be kind to others, assume responsibility, and choose the right response

Make sure goals are specific, measurable, attainable, relevant and time efficient
\end{abstract}

These results highlight that most respondents prioritise learning and skills improvement opportunities and workshops, courses, and training. In response, a conceptual framework (Fig. 3) for leadership development was developed, based on the research and results, discussed throughout this study. It provides a model for improving leadership quality and performance in Cape Town's construction industry, including coaching, empowerment, participation, training and development, and delegation.

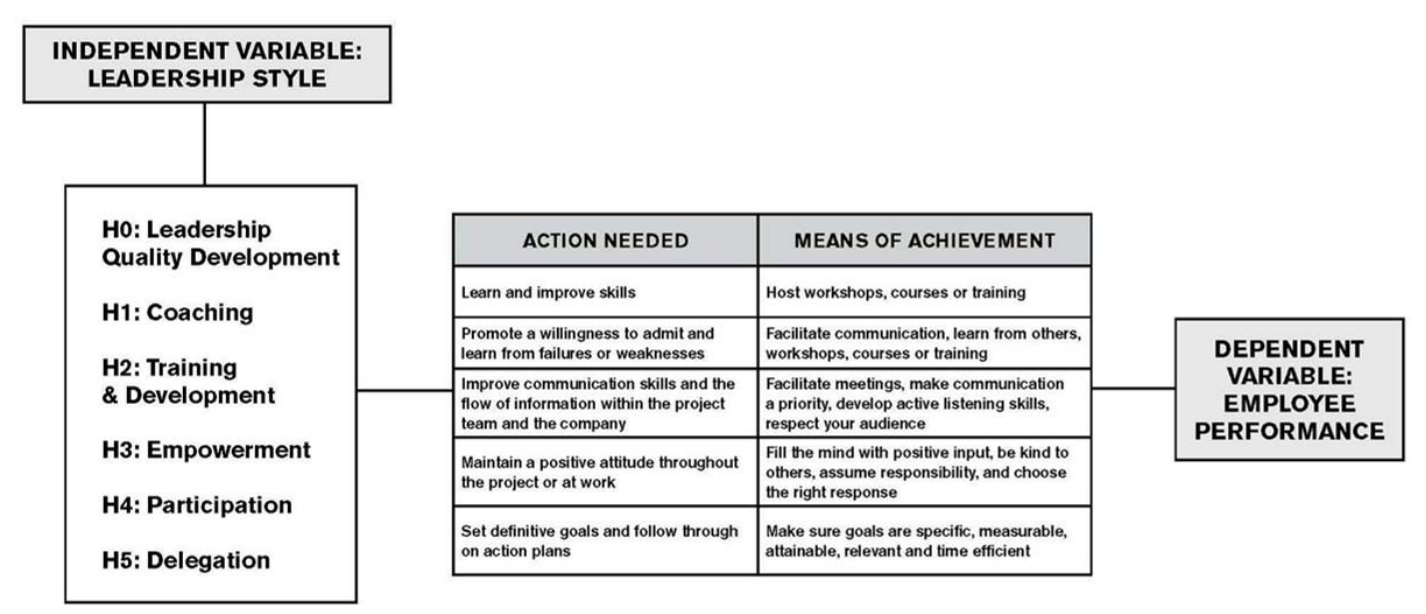

Fig. 3. Conceptual framework for leadership development. Source: Jabareen (2009)

\section{Discussion}

This two-way communication style encourages constructive feedback between project managers and subordinates, whereby project managers can point out areas that need improvement and offer solutions. Beyond immediate issues, coaching can help address entrenched belief systems, behaviours, and unhelpful habits that hinder positive performance, writes [31].

Training and development addresses skill deficits among employees, reduces the need for management supervision over time, and "improves the drive, initiative, and quality of work of employees, thus assisting them to be more committed to achieving the goals and objectives of the organisation" [32]. These methods can reduce feelings of inadequacy and increase motivation among employees, bridging the gap between desired and actual performance [32]. Training and development can be carried out formally (via workshops, courses, or conferences) or informally (learning from others on site).

Duvall a term often misunderstood, is a synergistic process of individual development through which the base of influence in an organization is enlarged. Individual empowerment requires that the philosophy of the organization, principally enacted through its administrative system, support employees in accomplishing organizational goals. This support comes from effective and efficient managerial allocation of organizational resources. Two different organizational 
philosophies are presented and discussed in terms of their im pact on empowerment: organizational resource conservation and organizational resource integration. The differences between the philosophies are explained through a conceptual model of preventing failure versus assuring success. The implications of each philosophy for the practice of management in k nowledge organizations are discussed. These implications are based on the assumption that managerial behaviors determine how successful will be the process of empowerment. Introduction It is predicted that over one-third of the companies on the Fortune 500 list will be dropped from the list over the next five years. The companies that have and will survive are those that are able to withstand constantly changing conditions both internal and external to the organization, to continuously innovate, and have the knowledge within the organization to make decisions directed at achieving organizational success (Choo, 1998[33] defines success as "achievement, accomplishment and attainment" and argues these are all empowerment outcomes. When team members share mutually beneficial experiences with themselves and their organisations, they feel more satisfied with their work. Empowerment, therefore, has "significant positive correlations with both performance and satisfaction" and was "more strongly correlated with the in-role performance of followers than with satisfaction with the leader" [34].

Researchers suggest participation can be a useful tool to encourage employees to use their talents and skills to address problems on site. When studying American and Chinese managers in China, Chen and Tjosvold including structural equation analyses, support the hypotheses that cooperative, but not competitive or independent, goals helped Chinese employees and their foreign and Chinese managers strengthen their quality relationships as measured by supervisor-subordinate guanxi and leader-membership exchange; quality relationships in turn enhanced effective participative leadership as measured by the opportunity for joint decision-making and the open-minded discussion of opposing views (constructive controversy[34] discovered that inviting employees into the decision-making process and creating an open environment could increase job performance and reduce turnover.

Delegation involves assigning tasks, responsibilities, and authority to employees; it describes various methods for power sharing with individual subordinates [35]. While there can be many reasons to delegate - including when a project manager is overwhelmed - one of the best reasons is to develop subordinates' skills and confidence.

Limitations and Delimitations. The research was limited to Cape Town construction companies, construction project managers and on-site construction workers. Due to the sheer number of construction companies in Cape Town, it proved difficult to gather data from every company and job site. As such, the research focused on companies with a noticeable presence in the city. Respondents were given questionnaires in person at construction companies and active job sites, ensuring all received proper instruction to complete the questionnaire. The study surveyed construction employees doing "general building construction," which consists of the erection of residential, industrial, and commercial buildings (rather than large-scale infrastructure projects like bridges and highways, or small, speciality trade contractors, such as carpenters, electricians or plumbers).

Recommendations for further study. This study has triggered several questions to be studied by future researchers:

- How do the demographics (age, race, level of education, etc.) of a project manager impact leadership styles and employee performance in the construction industry in Cape Town?

- How can construction companies develop and implement their own effective management framework models to improve leadership quality and performance in the construction industry in Cape Town based on leadership styles that are proven to be effective?

- What is the impact of leadership quality development tools on factors like employee productivity, performance, profitability, or behaviour?

\section{Conclusion}

The study addresses a void in the current body of industry knowledge and academic literature. In doing so, it can be used as a tool to improve the quality of leadership among project managers and the performance of employees in Cape Town's construction sector. 
This study highlights how the leadership styles of construction project managers have a significant impact on employee performance. The results show how subordinate employees perceive project managers' leadership styles; what works on site and what does not.

It is crucial to develop effective leadership in the construction industry. Improving leadership "requires fixed attention", particularly as the industry continues to face socio-economic, environmental, political, and economic challenges [36]. To improve employee performance, the following practical, managerial, and policy recommendations have been made:

- Project managers should consider how to implement transformational and democratic leadership styles in their daily work, as they were shown to have a positive impact on employee performance;

- Construction companies in Cape Town should invest time and financial resources towards leadership development workshops, training courses, and skills improvement;

- Construction companies should work to improve their project managers' communication skills and the flow of information within project teams and the wider company;

- Project managers should seek opportunities to empower potential leaders;

- Project leaders and subordinate employees should seek opportunities to improve morale through incentives (even if they are not financial) throughout the project.

From a policy perspective, the study can be used to inform the development of leadership training for project managers in Cape Town. Likewise, the conceptual framework can help improve their leadership, and subsequently, the performance of construction employees on site. By learning from and implementing new leadership styles that are more inclusive and participative, organisations can achieve better employee performance outcomes and improve their project outcomes.

\section{References}

[1] Del Caño, A., de la Cruz, M. P. (2002). Integrated Methodology for Project Risk Management. Journal of Construction Engineering and Management, 128 (6), 473-485. doi: http://doi.org/10.1061/(asce)0733-9364(2002)128:6(473)

[2] Liphadzi, M., Aigbavboa, C., Thwala, W. (2015). Relationship Between Leadership Styles and Project Success in the South Africa Construction Industry. Procedia Engineering, 123, 284-290. doi: http://doi.org/10.1016/j.proeng.2015.10.091

[3] Toor, S., Ofori, G. (2008). Taking leadership research into future. Engineering, Construction and Architectural Management, 15 (4), 352-371. doi: http://doi.org/10.1108/09699980810886856

[4] Daniel, C. O., Ugochuku, N. R. (2020). Influence of Project Managers Leadership Style on Project Implementation. International Journal of Business Marketing andManagemen, 5 (2), 68-76.

[5] Munirat, O. et. al. (2014). The relationship between leadership styles and employees' performance in organisations. European journal of business and management, 6 (22), 76-86.

[6] Sorenson, G. J., Goethals, G. R. (2012). Leadership Theories: Overview. Encyclopedia of Leadership. doi: http://doi.org/ 10.4135/9781412952392.n201

[7] Windapo, A. O., Cattell, K. (2013). The South African construction industry: Perceptions of key challenges facing its performance, development and growth. Journal of Construction in Developing Countries, 18 (2), 65-79.

[8] Price, J. J. (2009) The Conception and Operationalization of leadership in construction companies. University of South Africa, 206.

[9] Mohammad and Yarmohammadian (2006). A study of relationship between managers' leadership style and employees' job satisfaction'. Leadership in Health Services, 19 (2), 11-28. doi: http://doi.org/10.1108/13660750610665008

[10] Zulch, B. (2014). Leadership Communication in Project Management. Procedia - Social and Behavioral Sciences, 119, $172-181$. doi: http://doi.org/10.1016/j.sbspro.2014.03.021

[11] Schaeffer, L. D. (2002) The leadership journey. Harvard Business Review. Available at: https://hbr.org/2002/10/the-leadership-journey

[12] Boehm, S. A., Dwertmann, D. J. G., Bruch, H., Shamir, B. (2015). The missing link? Investigating organizational identity strength and transformational leadership climate as mechanisms that connect CEO charisma with firm performance. The Leadership Quarterly, 26 (2), 156-171. doi: http://doi.org/10.1016/j.leaqua.2014.07.012

[13] Chynoweth, C. (2008). Leaders who put onus on the led. The Times and Sunday Times, 1-2.

[14] Iqbal, N. A. S., Haider, N. (2015). Effect of Leadership Style on Employee Performance. Arabian Journal of Business and Management Review, 5. 
[15] Bhatti, N., Maitlo, G. M., Shaikh, N., Hashmi, M. A., Shaikh, F. M. (2012). The Impact of Autocratic and Democratic Leadership Style on Job Satisfaction. International Business Research, 5 (2). doi: http://doi.org/10.5539/ibr.v5n2p192

[16] Northouse, P. G. (2017) Comparing transformational, transactional and laissez-faire styles. Leadership: Theory and Practice. Thousand Oaks: Sage Publications, Inc.

[17] Warrilow, S. (2012) Transformational Leadership Theory - The 4 Key Components in Leading Change and Managing Change. E-Zine Articles. Available at: https://ezinearticles.com/?Transformational-Leadership-Theory---The-4-Key-Components-inLeading-Change-and-Managing-Change\&id=2755277

[18] Odumeru, J., Ifeanyi, G. (2013). Transformational vs. transactional leadership theories: evidence in Literature. Internationational Review of Management and Business Research, 2 (2), 355-361.

[19] Ponterotto, J. G. (2005). Qualitative research in counseling psychology: A primer on research paradigms and philosophy of science. Journal of Counseling Psychology, 52 (2), 126-136. doi: http://doi.org/10.1037/0022-0167.52.2.126

[20] Brent, E., Leedy, P. D. (1990). Practical Research: Planning and Design. Teaching Sociology, 18 (2), 248. doi: http://doi.org/ $10.2307 / 1318509$

[21] Bhattacherjee, A. (2012). Social Science Research: Principles, Methods, and Practices. Available at: https://digitalcommons. usf.edu/oa_textbooks/3

[22] Bihani, P., Patil, S. T. (2014). A Comparitive Study of Data Analysis Techniques. International Journal of Emerging Trends and Technology in Computer Science.

[23] Carmines, E., McIver, J. (1981). Analyzing models with unobserved variables: Analysis of covariance structures. Social measurement: Current issues, 65-115.

[24] Nunnally, J., Bernstein, I. (1994). Psychometric Theory. New York McGraw-Hill, 752.

[25] Lim, E., Alum, J. (1995). Construction productivity: Issues encountered by contractors in Singapore. International Journal of Project Management, 13 (1), 51-58. doi: http://doi.org/10.1016/0263-7863(95)95704-h

[26] Cronbach, L. J. (1951). Coefficient alpha and the internal structure of tests. Psychometrika, 16 (3), 297-334. doi: http://doi. $\operatorname{org} / 10.1007 /$ bf02310555

[27] Hopkins, W. G. (2000). Measures of Reliability in Sports Medicine and Science. Sports Medicine, 30 (5), 375-381. doi: http:// doi.org/10.2165/00007256-200030050-00006

[28] King, W. R., He, J. (2006). A meta-analysis of the technology acceptance model. Information \& Management, 43 (6), $740-755$. doi: http://doi.org/10.1016/j.im.2006.05.003

[29] Marshall, E. (2017). One-way (between-groups) ANOVA steps in SPSS.

[30] Uyanık, G. K., Güler, N. (2013). A Study on Multiple Linear Regression Analysis. Procedia - Social and Behavioral Sciences, 106, 234-240. doi: http://doi.org/10.1016/j.sbspro.2013.12.027

[31] Du Toit, A. (2007). Making sense through coaching. Journal of Management Development, 26 (3), 282-291. doi: http://doi. org/10.1108/02621710710732164

[32] Sahinidis, A. G., Bouris, J. (2008). Employee perceived training effectiveness relationship to employee attitudes. Journal of European Industrial Training, 32 (1), 63-76. doi: http://doi.org/10.1108/03090590810846575

[33] Duvall, C. K. (1999). Developing individual freedom to act: Empowerment in the knowledge organization. Participation and Empowerment: An International Journal, 7 (8), 204-212. doi: http://doi.org/10.1108/14634449910303603

[34] Bartram, T. and Casimir, G. (2007) 'The relationship between leadership and follower in role performance and satisfaction with the leader: The mediating effects of empowerment and trust in the leader', Leadership and Organization Development Journal, 28 (1), 4-19. doi: http://doi.org/10.1108/01437730710718218

[35] Chen, Y. F., Tjosvold, D. (2006). Participative Leadership by American and Chinese Managers in China: The Role of Relationships. Journal of Management Studies, 43 (8), 1727-1752. doi: http://doi.org/10.1111/j.1467-6486.2006.00657.x

[36] Yukl, G. (2002). Leadership In Organizations (5th Edition) Gary Yukl Fag: Organisation. Management, 9 (1), 16-32.

Received date 22.08.2021

(C) The Author(s) 2021

Accepted date 15.09.2021

Published date 30.09.2021

This is an open access article under the Creative Commons CC BY license

How to cite: Kalambayi, J. L., Onojaefe, D. P., Kasse, S. N., Tengeh, R. K. (2021). The influence of leadership styles on employee performance in construction firms. EUREKA: Social and Humanities, 5, 34-48. doi: http://doi.org/ 10.21303/2504-5571.2021.002037 